\title{
THE STATUS OF THE GREAT GRAY OWL IN MANITOBA, WITH SPECIAL REFERENCE TO THE 1968-69 INFLUX
}

\author{
by Robert W. Nero, Manitoba Museum of Man and Nature, Winnipeg \\ Photography by Robert R. Taylor, Manitoba Museum
}

The occurrence of a Great Gray Owl influx in extreme southeastern Manitoba became evident on December 8,1968 , when seven owls were sighted by a party of three observers. On the following day another party counted 12 in the same general area. Thereafter, a concerted effort was made to follow the course of what stands as the largest influx yet reported for Manitoba. Thanks to the cooperation of many interested persons, it has been possible to record in some detail this interesting movement of owls.

Although the Great Gray Owl (Strix nebulosa) is a permanent resident of the province, it is generally unknown sutside its breeding grounds in the northern coniferous forest except in late fall and winter when it occasionally appears to the southward. Even within its breeding grounds it is a rare and retiring owl and is seldom observed. Hence, the majority of records for Manitoba are of winter wanderers.

\section{Range and General Status}

The breeding range in Manitoba as depicted by Godfrey $(1966: 218)$ is presumed to cover most of the boreal forest zone (Figure 1). Nest records are needed to substantiate this picture, only three being known for Manitoba. A nest found at Dauphin Lake in 1926 by E. Robinson (Lawrence, 1926b; Robinson, 1954) actually lies outside the coniferous forest (see Figure 1) and was possibly an extralimital nesting; the species is not believed to occur as a resident in that area today. It was unrecorded in Riding Mountain National Park, 20 miles to the southwest, until 1969. Fifty miles to the northeast at Lake St. Martin the species was considered by Shortt and Waller (1937: 28) to be a "rather rare fall and winter visitor ... not known to nest in the area." Two other nestings are both for The Pas, 170 miles northwest of Dauphin Lake, one in 1964 (Parmalee, 1968), the other (in the same nest!) in 1968 (Mitchell,1969; Nero, MS). P. Reader, resident at Reader Lake, 10 miles north of The Pas, discovered both of these latter nests. Museum staff visited the 1968 nest site on three occasions in April, May and June. Considerable photographic coverage was obtained and a detailed report is in press.

Records of the Great Gray Owl in extreme northern Manitoba are few. It has not been recorded at Churchill (Taverner and Sutton, 1934) except for one record, one seen by C. A: Harwell and Hazel Ellis on June 18, 1949; Lawrence, 1949; Jehl and Smith, MS). Two specimens were received from J. P. Gardiner at York Factory, probably from farther inland, sometime prior to 1860 (Blakiston, 1863). More recently, on March 27, 1969, a Churchill handicraft store offered for sale two beaded ornaments made out of facial feather discs from two Great Gray Owls by a Cree Indian at Herchmer, 75 miles northwest of York Factory. At least one of these owls was shot at Herchmer in 1969 (pers. corres., Miss Betty Redhead, 1969). It may be more than coincidence that Herchmer is near Owl Lake and Owl River. Farther south at Thompson, two were reported seen by T. Lindsey in December, 1966 (Mossop, 1966). S. Waller (pers. corres., 1969) has records of specimens from Herb Lake: December 10, 1949, and Wekusko Lake (Puella Bay): December 17, 1942, about 95 miles southwest of Thompson. Waller also recorded six specimens from or near The Pas where it has twice been 
found nesting (above): November 18, 1939, September 25, 1950, December 18, 1950, March 26, 1961, February 22, 1966, and April 25, 1967. A specimen in the Manitoba Museum of Man and Nature was obtained from The Pas in July, 1950. Waller lists two additional specimens from Cedar Lake (now inundated by reservoir waters), southeast of The Pas: January 26, 1956, and February 4, 1956. The earliest reference to the species in The Pas region is by Vogt (1935) who visited an area south of Moose Lake in August, 1935, and wrote, "In the upper reaches of the journey we flushed several Great Gray Owls." The above

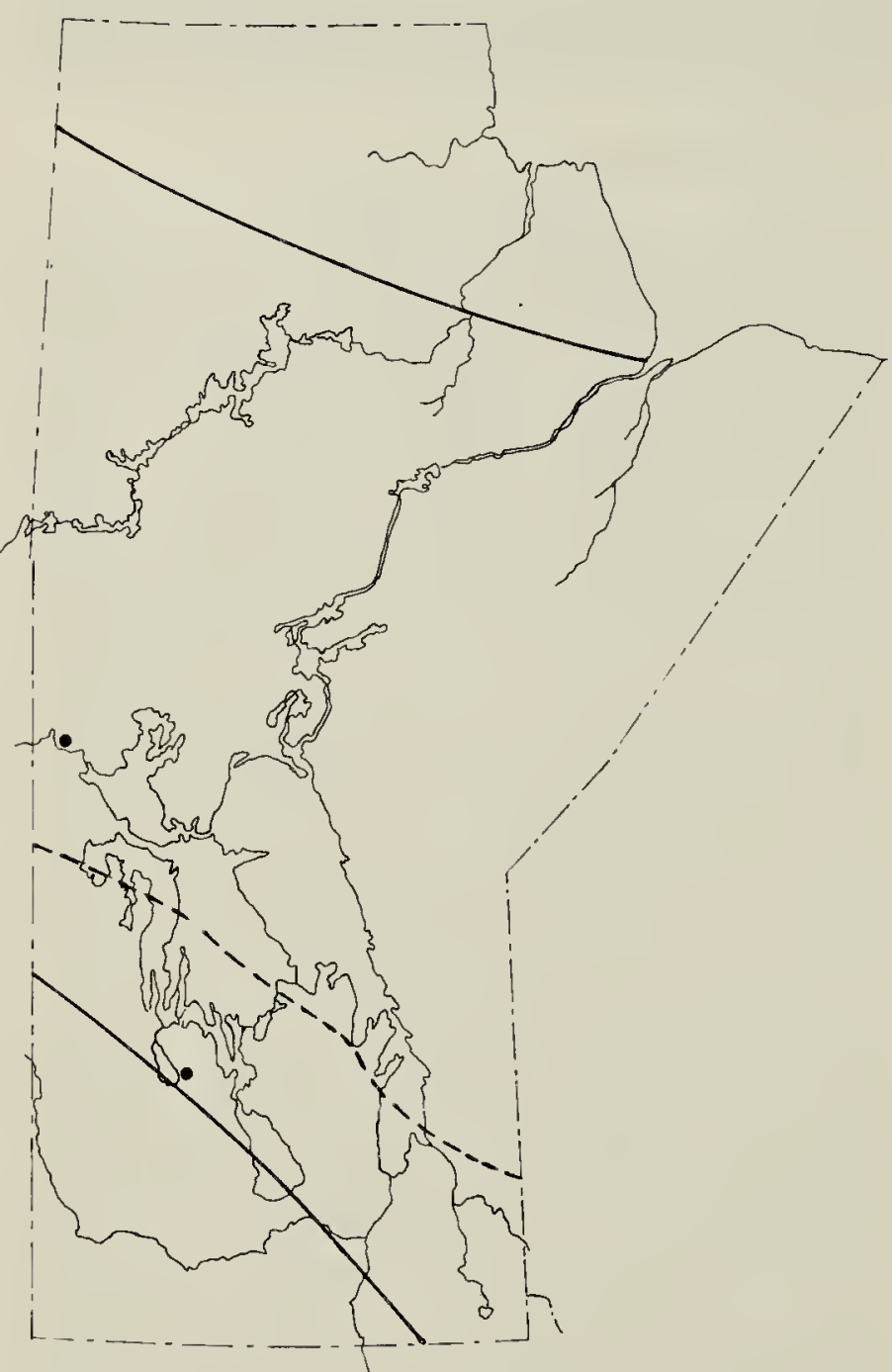

Figure 1. Location of the two known nest sites of the Great Gray Owl in Manitoba. The solid lines mark the bounds of the breeding range as given by Godfrey $(1966: 218)$. The dashed line shows the approximate southern boundary of the northern coniferous forest (from Weir, 1960:21). Numerous stands of conifers occur with deciduous trees to the south of the line, but north of the line black spruce, white spruce and balsam fir predominate. records are all from north of the 53rd parallel.

In southern Manitoba, a specimen was collected in the 1850 's by Donald Gunn at Selkirk (then "Selkirk Settlement") for the Smithsonian Institution (Baird, Cassin, and Lawrence, 1860: 56). Thompson (1890:541) describes a specimen collected on September 29, 1884 at Carberry; he considered this species a "rare winter visitant" in southern Manitoba. A specimen in the Royal Ontario Museum was collected at Winnipeg on January 20, 1897 (pers. corres., J. C. Barlow). Additional records since then and prior to the fall of 1968 are given in Table 1.

The present data show that the Great Gray Owl has been recorded in southern Manitoba at least one or more times in 26 of the years in a 70 year period (1900-1969). So far as can be determined, numbers of three or more have been reported only for the winter periods of 1922-23, 1933-34, $1959-60,1962-63$, and 1964-65. The longest periods for which records are lacking are the 11 years from 1900 to 1910 and the eight years from 1937 to 1945 . Where known, most records are from October to February inclusive, with highest counts in November, December and January.

The first report of an unusual number is given by Lawrence (1928) who stated: "H. Hatton and C. G. Harrold, Winnipeg, report that a small flight of these rare owls occurred in southern Manitoba in the fall of 1924, and a number were shot by gunners." This date appears to be an error and should presumably be referred to 1922 , for Lawrence makes no reference to the specimens obtained by Harrold in the winter of 1922-23 (see Table 1). Lawrence reported only six other observations of Great Gray Owls between 1921 and 1955, the years of his column, and lists but one other record (in his 1933 notebook; see Table 1). Mossop states (1966): "During the winter of 1922-23 . . . an invasion occurred in the Winnipeg area when, because of their lack of fear of man, 


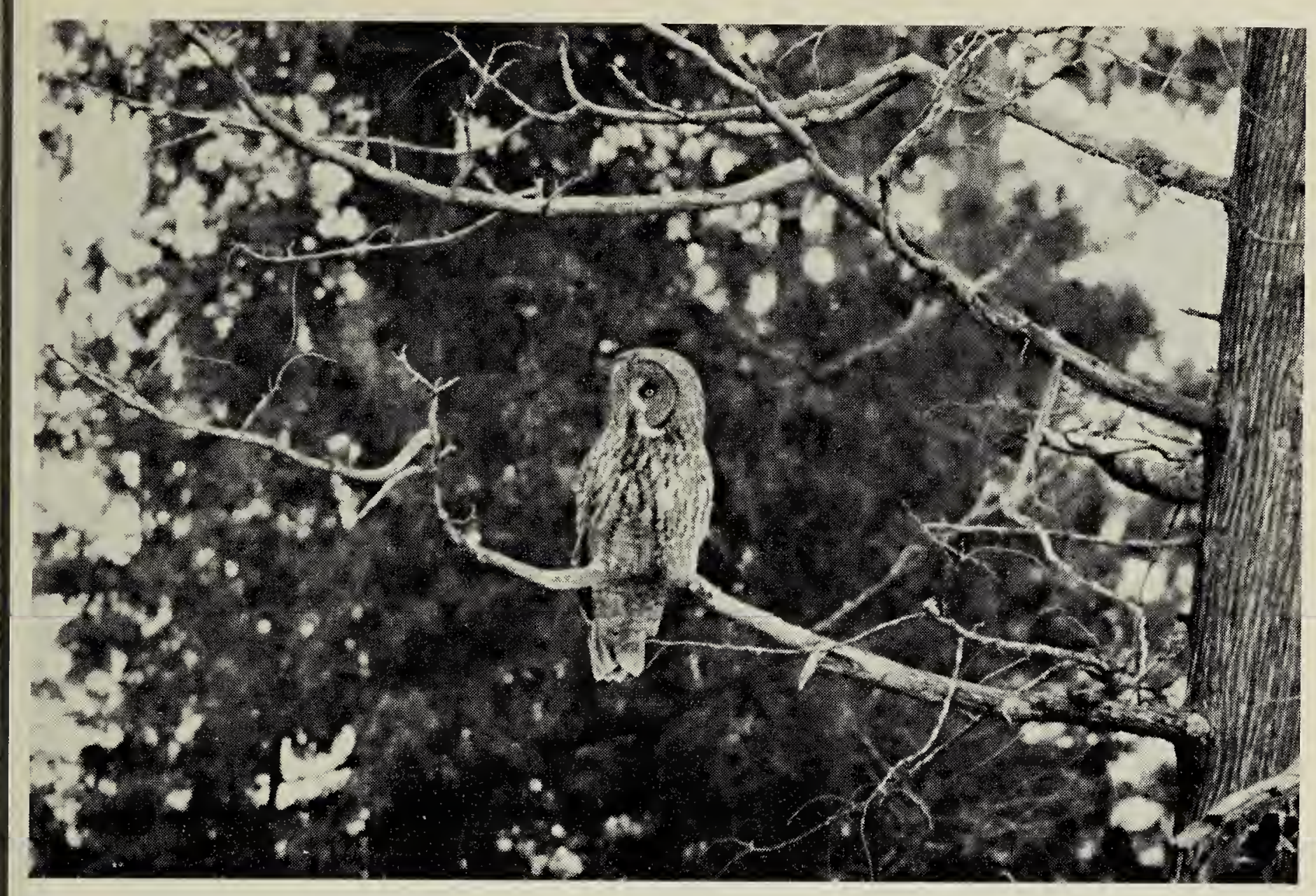

Great Gray Owl in white cedar (see also cover).

numbers were shot by irresponsible gunners." Mossop, who was a teenaged boy at the time, reports (pers. corres., 1969) that he moved to St. Vital (Winnipeg suburb) in 1922, and that winter witnessed a "large invasion" in the St. Vital woods. Several owls were shot each Saturday by schoolboys with .22 rifles, these owls being brought wounded or dead to school for identification. Mossop said he saw possibly 20 Great Gray Owls that winter while on his way to school or on Saturday outings.

\section{8-69 Influx, General Aspects}

Automobile transportation in winter in the twenties and thirties in Manitoba was not so readily available as today. Moreover, modern highways make it possible to traverse large areas that formerly were more remote. The development of lake cottages and weekend trips to the country, even in winter, has led to an increased number of observers being afield. Large-scale movements of owls are not likely to escape our attention these days, but prior to, say 1940 , they could have. The years in which Great Gray Owls have previously been reported in southern Manitoba, even in limited numbers (Table 1), may, in fact, represent years of significant movements. Still, it is clear that over the past 20 years, at least, there has not been any influx of the magnitude observed in 1968-69. Thus, this event is probably a unique phenomenon for Manitoba. In northeastern Minnesota, where there have been only one or two sightings each winter since 1950 , the winters of 1965-66 and 1968-69 were major influx periods (Green, 1966, 1969).

Owl records for the fall, winter and spring seasons of 1968-69 are listed in Table 2 (excluding a few additional reports for which identification was uncertain). The distribution of these records is shown in Figure 2. As shown in Table 2, Great Gray Owls appeared in early October, 1968, apparently increased in number in November, reached a maximum number in December, and remained in 

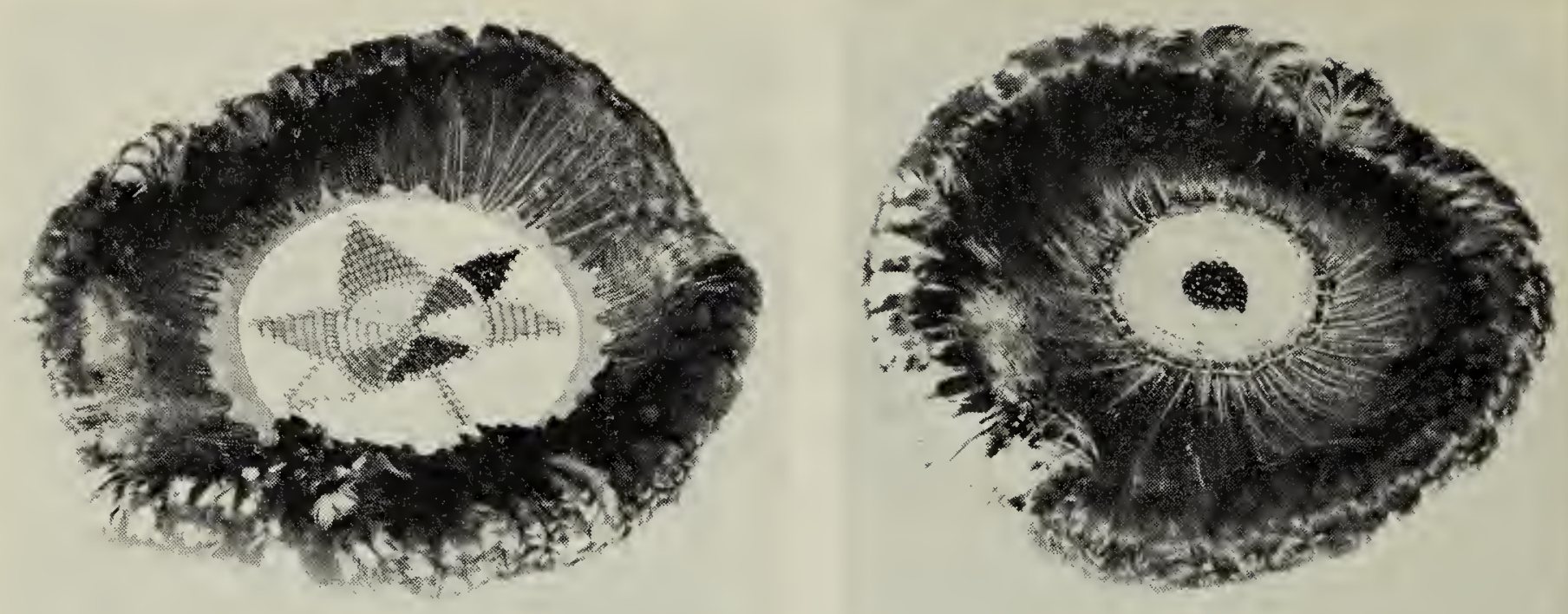

Cree Indian beaded ornaments made from Great Giay Owl facial discs or ear coverts, Herchmer, Manitoba, 1969. The one on the left, which is made of two discs, bears the Canada 1967 Centennial official design-an interesting example of acculturation. Two other similar ornaments, yrobably obtained from the Hodgson area, 1922-27, are in the Manitoba Museum of Man \& Nature.

high numbers until the third week in January. After that time a marked decrease was observed, particularly in an area of concentration along Trans-Canada Highway No. 1. Thereafter, smaller numbers were observed (roughly the same number as in October) in March, April, and May. With each successive month, it may be noted, owls were reported in from two to six new localities. This suggests that as the season advanced there was an actual increase in the number of owls in the area. Single and multiple sightings and records were obtained altogether from about 30 localities.

Two features of this influx are noteworthy: one, the large number of owls; two, the relatively small portion of Manitoba comprising the influx area (see Table 2 and Figure 2). The total number of owls involved must range upwards of 50 to 100 . Note that 14 dead owls were counted to January 5 , at which time 12 live ones were seen in one small area (Hadashville to Falcon Lake). Nine seen in the same area on December 2 and January 18 , plus 12 seen at distant points in this period give a minimum of 35 . However, other observers reported large numbers elsewhere during this period. R. Blanchard noted seeing "as many as 15 birds in one day" between Ste. Rita and Whitemouth (20 miles) at various times during the fall and winter. Although activities are restricted in winter, Parks Branch field staff reported seeing owls from December onwards (not listed in Table 2) in several areas in the Whiteshell Provincial Park. In view of the broad distribution of owls and the large, remote tracts of suitable habitat that were not examined, it seems plausible to set the estimate at 100 birds. This is somewhat less than the earlier estimate of "a few hundred" (Blue Jay, 27:39-40) .

Although the main influx area covered about 10,000 square miles (roughly, that portion of Manitoba south of Lake Winnipeg and east of Winnipeg), owls were most abundant in the northern and eastern section of about 3600 square miles. During the same observation period Great Gray Owls were seen in Minnesota over a much larger area, more than 300 miles from north to south, the northern portion alone covering 30,000 square miles (from data by Green, 1969). It is not known, however, whether owls were distributed throughout this region. From the "very end of December through the first week of January, 
Table 1. Great Gray Owl records for southern Manitoba, prior to fall 1968

\begin{tabular}{|c|c|c|c|}
\hline Date & Number & Location & Observer (s) \\
\hline 1911(?) & 1 captive & Winnipeg & A. G. Lawrence (1928) \\
\hline 1917 February & 1 specimen & Swan Lake & C. G. Harrold (in Man. Mus.) \\
\hline 1918 February & 1 seen & Kalevala & E. S. Norman $(1920)$ \\
\hline 1922 December 10 & 1 specimen & Waugh & C. G. Harrold (in Man. Mus.) \\
\hline 1923 January 6 & 1 specimen & Beausejour & C. G. Harrold (Man. Mus.) \\
\hline$"$ January 6 & 1 specimen & Winnipeg & C. G. Harrold (Man. Mus.) \\
\hline$" \quad$ December 22 & 1 specimen & Moosehorn & C. G. Harrold (Man. Mus.) \\
\hline 1926 & remains in $\mathrm{G}$ & den Eagle & A. G. Lawrence (1926a) \\
\hline 1928 February 14 & 1 seen & Teulon & H. D. Cumming (Lawrence, \\
\hline 1933 January & 2 seen & Whitemouth & V. Latta (Lawrence, 1933) \\
\hline " December 3 & 1 specimen & Whitemouth & $\begin{array}{r}\text { McQuade (Lawrence note- } \\
\text { book) }\end{array}$ \\
\hline 1934 January & 2 seen & Whitemouth & V. Latta (Lawrence, 1934) \\
\hline 1935 November 7 & 1 specimen & $\begin{array}{l}\text { Lake St. } \\
\text { Martin }\end{array}$ & Shortt and Waller (1937) \\
\hline 1936 December 27 & 1 seen & Stonewall & $\begin{array}{l}\text { I. M. Gardner (pers. corres. } \\
\text { K. Gardner, 1969) }\end{array}$ \\
\hline 1945 November (late) & 2 specimens & Sandilands & $\begin{array}{l}\text { H. Mossop (1965; pers. } \\
\text { corres., 1969) }\end{array}$ \\
\hline 1948 or 49 & 1 seen & Selkirk & G. Beck (pers. corres., 1969) \\
\hline 1950 December 2-3 & 2 seen & Petersfield & S. Wick (Lawrence, 1950) \\
\hline 1951 January 12 & 1 seen & Stonewall & K. Gardner (Shortt, 1951) \\
\hline 1952 October 24 & 1 seen & Clarkleigh & $\begin{array}{l}\text { K. Gardner (pers. corres., } \\
\text { 1969) }\end{array}$ \\
\hline 1955 December 8 & 2 seen & Marchand & $\begin{array}{l}\text { A. Ferguson (Mossop, } 1956 \\
\text { and pers. corres.) }\end{array}$ \\
\hline 1959 November 21 & & & A. Shortt (1959) \\
\hline " November 30 & 1 seen & Woodridge & $\begin{array}{l}\text { K. Gardner (pers. corres., } \\
1969 \text { ) }\end{array}$ \\
\hline$"$ December 20 & $\begin{array}{l}1 \text { found } \\
\text { shot }\end{array}$ & $\begin{array}{l}\text { Winnipeg } \\
\text { (Charles- } \\
\text { wood) }\end{array}$ & H. Mossop (1959) \\
\hline 1962 December 16 & 1 seen & $\begin{array}{l}\text { Beausejour } \\
\text { (11 mi. E.) }\end{array}$ & $\begin{array}{l}\text { G. Smith (Nat. Hist. Soc. } \\
\text { Man. Newsletter No. } 2 \text {, } \\
\text { Fall 1962) }\end{array}$ \\
\hline winter & $\begin{array}{l}\text { numbers } \\
\text { seen }\end{array}$ & $\begin{array}{l}\text { Riverton } \\
(\mathrm{NW})\end{array}$ & $\begin{array}{l}\text { T. L. Couture (pers. corres., } \\
\text { 1969) }\end{array}$ \\
\hline 1963 winter & $\begin{array}{l}\text { numbers } \\
\text { seen }\end{array}$ & $\begin{array}{l}\text { Riverton } \\
(\mathrm{NW})\end{array}$ & $\begin{array}{l}\text { T. L. Couture (pers. corres., } \\
\text { 1969) }\end{array}$ \\
\hline February 15 & 1 seen & $\begin{array}{l}\text { Gypsumville } \\
(15 \mathrm{mi} . \mathrm{W})\end{array}$ & R. Frisch \\
\hline March 23 & 1 seen & $\begin{array}{l}\text { Gypsumville } \\
(15 \mathrm{mi} . \mathrm{W})\end{array}$ & R. Frisch \\
\hline 1964 November & 2 seen & Sprague & J. Olson (Mossop, 1965) \\
\hline 1965 April & 1 seen & Sprague & J. Olson (Mossop, 1965) \\
\hline$" \quad$ November 16 & 1 seen & $\begin{array}{l}\text { Steeprock } \\
(5 \mathrm{mi} . \mathrm{W})\end{array}$ & $\begin{array}{l}\text { I. M. Gardner (pers. corres. } \\
\text { K. Gardner, 1969) }\end{array}$ \\
\hline 1966 & 1 specimen & Teulon area & $\begin{array}{l}\text { K. Hawkins (pers. corres., } \\
\text { 1969) }\end{array}$ \\
\hline 1967 Octobrer (late) & 1 seen & $\begin{array}{l}\text { Braintree } \\
(6 \mathrm{mi} . \mathrm{S})\end{array}$ & $\begin{array}{l}\text { D. Raveling (pers. corres., } \\
1969 \text { ) }\end{array}$ \\
\hline$" \quad$ November & 1 seen & Hadashville & $\begin{array}{l}\text { D. Raveling (pers. corres., } \\
1969 \text { ) }\end{array}$ \\
\hline 1968 April 14 & $\begin{array}{l}1 \text { specimen } \\
\text { (found shot) }\end{array}$ & Mafeking & R. R. Taylor (Man. Mus.) \\
\hline June & 1 specimen & $\begin{array}{l}\text { Berens } \\
\text { River }\end{array}$ & $\begin{array}{l}\text { Miss B. Malyon (pers. } \\
\text { corres., 1969) }\end{array}$ \\
\hline
\end{tabular}


a big influx occurred in the Duluth area ... From late January through early March ... reports of about 20 owls from the Twin Cities area ... few reports after the first week of March . . ." (Green, 1969). Since Minnesota is outside the usual breeding range for this species, it may be assumed that all the records from that state were wanderers from farther north.

The Manitoba influx area may also be outside the usual breeding range of the species (Figure 2). There are no known summer records for this area, apart from birds that apparently stayed on after the influx (May records, Table 2). Although many square miles of habitat within this area seem suitable for nesting, particularly in the north and northeastern portions, the presence there of numerous cottage owners and summer visitors, coupled with a lack of reports, suggests that the Great Gray Owl is not normally present in the breeding season.
Even winter records are not common for this area. E. Schindler, a forester residing at Falcon Lake, said that a Great Gray Owl seen by him in October 1968 was the first that he had ever seen. W. Eliuk, a pulp-wood contractor living at Woodridge, said that though he covers a great deal of southeastern Manitoba during the winter months, one seen in December 1968 was the first he had seen. W. Prodkowsky, resident at Prawda, said he had not seen any for many years previous to 1968 .

A majority of the records of Great Gray Owls in southern Manitoba from the period for 50 years prior to 1968 are from the present influx area (Table 1). Of the 37 individuals listed, 25 or 68 per cent fall within this area. This may mean that the area is more often visited by Great Gray Owls than other areas in southern Manitoba or else that there are more observers here. The former explanation seems more reasonable. This leads one to conclude that owls find this area particularly

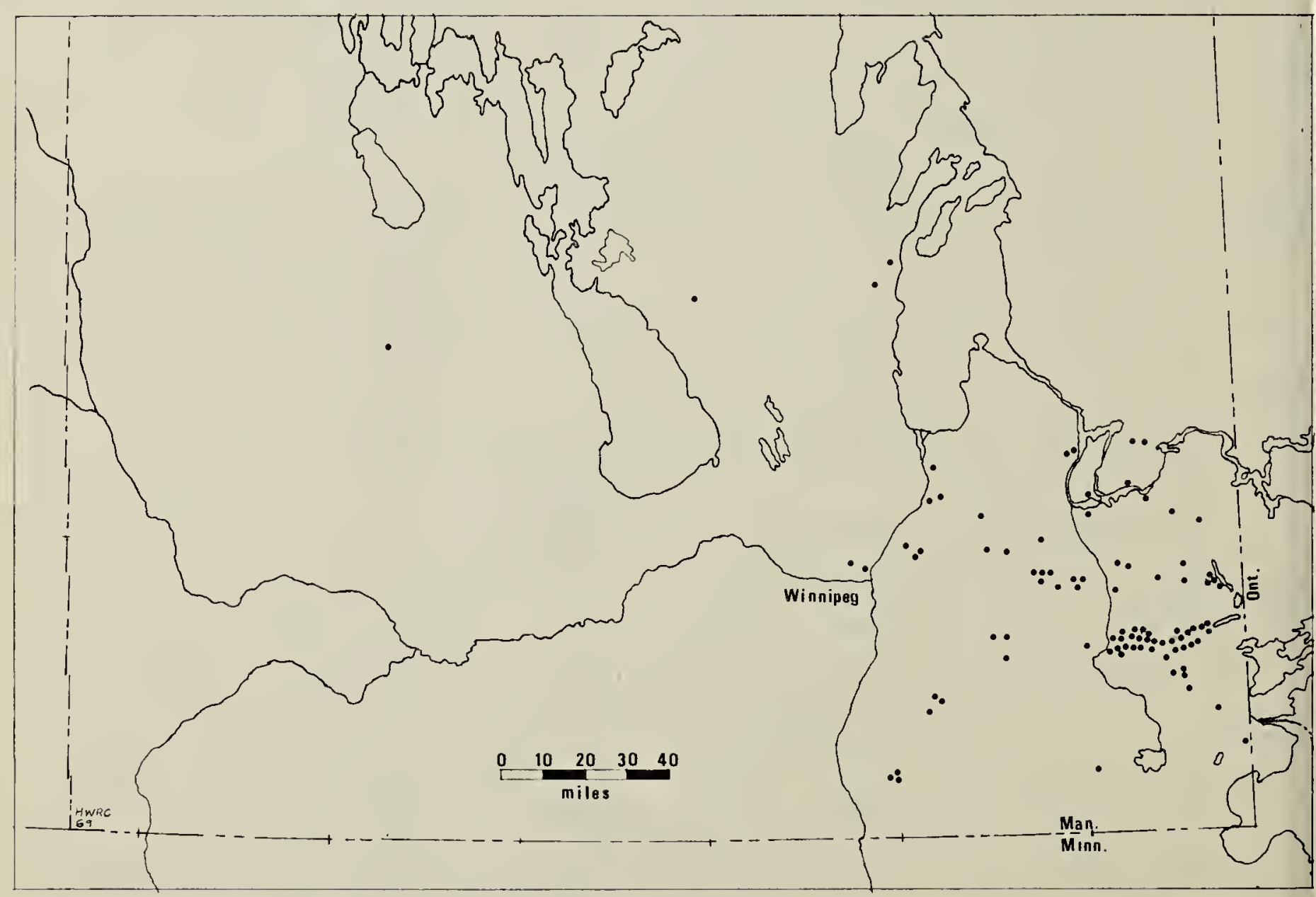

Figure 2. Great Gray Owl occurrence in southern Manitoba, winter 1968-69. One or more owls were reported seen or found dead at the localities shown. Winnipeg lies at the junction of the Red and Assiniboine rivers. 


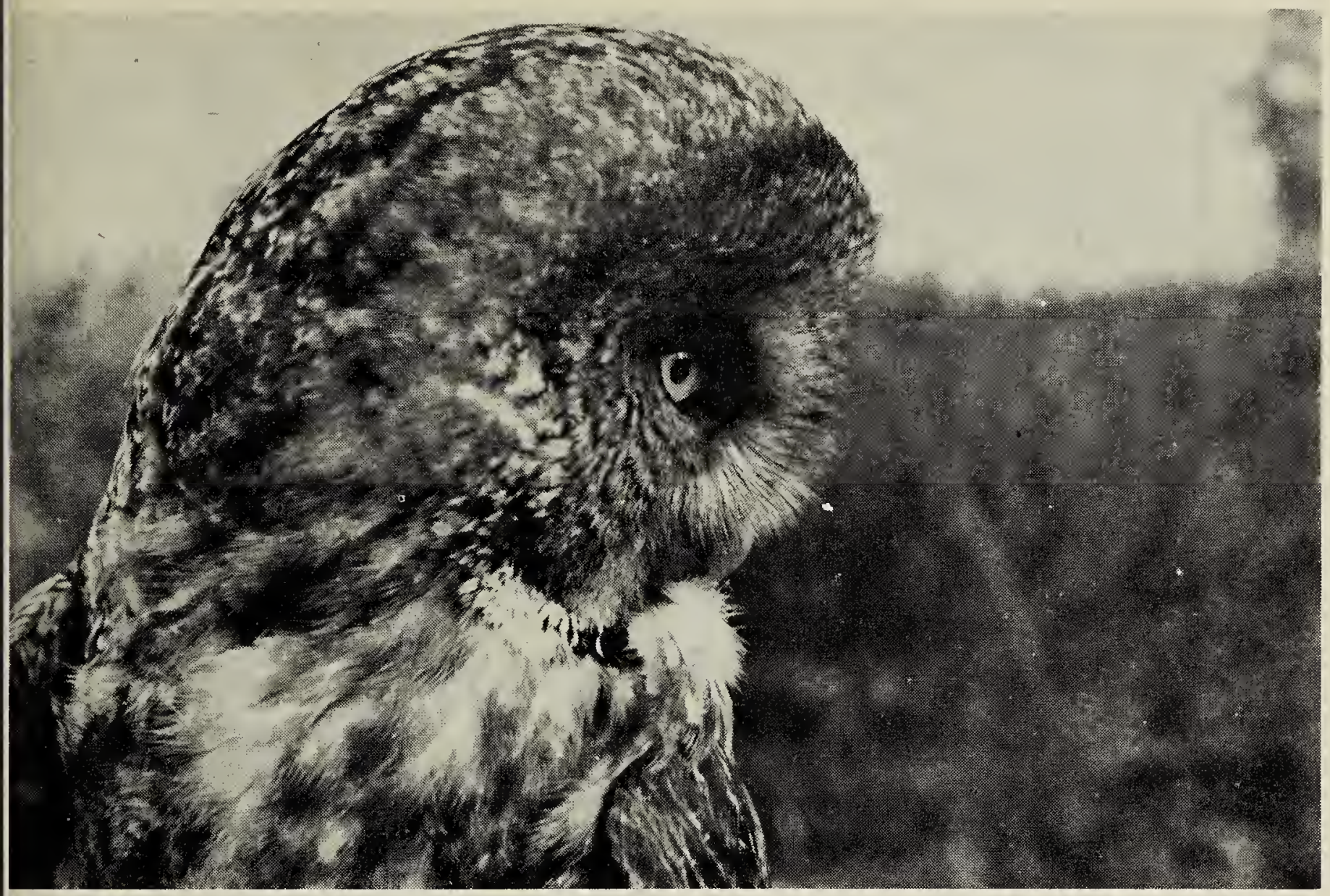

Great Gray Owl in hand for banding

attractive or else that it is close to well-populated Great Gray Owl breeding grounds. It is also possible that weather conditions, e.g., snowfall, in adjacent regions are more apt to force Great Gray Owls to move out of their breeding grounds.

Whatever the reasons, the prevalence of owls in the area from Winnipeg east ties in with observations made to the south. In Minnesota, winter wanderers are "normally most common in the northwestern part of the state" (Green, 1966). This does not necessarily mean that birds in this part of Manitoba and Minnesota originate in Manitoba. They could equally well come from Ontario. A "major invasion" in northeastern Minnesota in 1965-66, mostly observed along the north shore of Lake Superior, was accompanied by only one sighting in Manitoba, and that was at Sprague in the extreme southeastern corner. Allin (1966:66) noted an absence of birds at the Lakehead "at the time they were regularly reported at Duluth and north to "Tofte" but later in the season in March they "had several reports which may have represented birds returning to their northern homes." During the recent period of abundance of owls in southeastern Manitoba, they seemed to be absent in adjacent Ontario. M. Dederick, travelling by car from Winnipeg through western Ontario (to Kenora, Dryden, Atikokan, Fort William, etc.) every three or four weeks, saw owls only near Falcon Lake beginning November 20, 1968. A Winnipeg resident and falconer, Dederick had been driving this route since 1967 , but the Great Gray Owls seen on November 20 were the first abserved by him at any time.

Influx years in northwestern Minnesota do not always match influxes in Manitoba, but there is some correlation. Records show that owls were abundant in the years 1896-97, 190607, 1922-23, and 1926-27. At Roseau, just 10 miles south of the border (and less than 20 miles west of the southeast corner of the province), one observer noted that it was especially abundant in 1906-07 and again in 1926-27 when 18 owls were brought to 
Table 2. Great Gray Owl records 1968-1969

\begin{tabular}{|c|c|c|c|c|}
\hline \multicolumn{2}{|c|}{ Date } & Number & Location & \multirow{2}{*}{$\frac{\text { Observer (s) }}{\text { D. C. Purvis }}$} \\
\hline October & 4 & 1 specimen (shot) & Richer (area) & \\
\hline$"$ & 8 & 1 seen & Anola $(8 \mathrm{mi} . \mathrm{NE})$ & R. Webb \\
\hline$"$ & 12 & $\begin{array}{c}1 \text { specimen (found } \\
\text { shot) }\end{array}$ & $\begin{array}{l}\text { East Braintree } \\
\quad\left(\frac{1}{2} \mathrm{mi} . \mathrm{S}\right)\end{array}$ & G. A. Peever \\
\hline$" 23$ & $3-30 ?$ & 1 seen & Hadashville (E) & E. Schindler \\
\hline Novembe & er & 1 specimen (road & $\begin{array}{l}\text { Lac du Bonnet } \\
\quad\left(2 \frac{1}{2} \mathrm{mi} . \mathrm{N}\right)\end{array}$ & W. Schwartz \\
\hline$"$ & 9 & 2 seen & Elma ( 6 mi. W) & R. W. Nero \\
\hline$"$ & 9 & 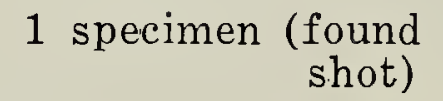 & Carrick (SE) & L. Konig \\
\hline$"$ & 11 & 1 seen & $\begin{array}{l}\text { Nutimik }\left(\frac{1}{2} \mathrm{mi} . \mathrm{S} \text { in }\right. \\
\text { the Whiteshell })\end{array}$ & R. Starrdom \\
\hline$"$ & 12 & 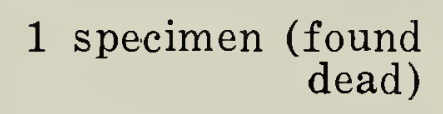 & Arborg $(5 \mathrm{mi} . \mathrm{E})$ & P. Lachuta \\
\hline$"$ & 20 & 3 or 4 seen & Falcon Lake area & M. Dederick \\
\hline$"$ & 23 & 1 seen & Elma (3 mi. SE) & $\begin{array}{l}\text { Nero and } \\
\text { R. R. Taylor }\end{array}$ \\
\hline$"$ & 23 & 1 specimen (shot) & Richer (area) & D. C. Purvis \\
\hline & & 1 specimen (found & $\begin{array}{l}\text { East Braintree } \\
(10 \mathrm{mi} . \mathrm{S})\end{array}$ & M. Gagnon \\
\hline$"$ & 25 & 4 or 5 seen & Falcon Lake area & M. Dederick \\
\hline Decembe & 1 & 7 seen & Richer to Falcon Lake & $\begin{array}{l}\text { M. K. McNicholl, } \\
\text { V. H. Scott and } \\
\text { Taylor }\end{array}$ \\
\hline$"$ & 2 & 12 seen & Richer to Falcon Lake & $\begin{array}{l}\text { Copland, Nero } \\
\text { and Taylor }\end{array}$ \\
\hline$"$ & 5 & 5 seen & Richer to Falcon Lake & $\begin{array}{l}\text { Copland, Nero, } \\
\text { Taylor and } \\
\text { W. Renton }\end{array}$ \\
\hline " & $1-7 ?$ & 1 seen & $\begin{array}{l}\text { East Braintree } \\
\quad(20 \mathrm{mi} . \mathrm{S})\end{array}$ & W. Eliuk \\
\hline$"$ & 14 & 2 seen & Falcon Lake area & Mrs. G. Keith \\
\hline$"$ & 15 & 3 seen & $\begin{array}{l}\text { Hadashville to Falcon } \\
\text { Lake }\end{array}$ & $\begin{array}{l}\text { A. H. Andersion } \\
\text { and Copland }\end{array}$ \\
\hline$"$ & $20 ?$ & 3 seen & $\begin{array}{l}\text { East Braintree } \\
\quad(5-6 \mathrm{mi} . \mathrm{S})\end{array}$ & F. Hayword \\
\hline$"$ & 21 & 2 seen & $\begin{array}{l}\text { Prawda, Moose Lake } \\
\quad \text { area }\end{array}$ & $\begin{array}{l}\text { Copland and } \\
\text { G. J. Smith }\end{array}$ \\
\hline$"$ & 28 & 1 seen & Steinbach (5 mi. SW) & T. Wiens \\
\hline$"$ & 29 & 1 seen & $\begin{array}{l}\text { Pointe du Bois ( } 5 \mathrm{mi} \text {. } \\
\text { W) }\end{array}$ & W. J. Schwartz \\
\hline$"$ & 29 & 2 seen & Prawda, Falcon Lake & Copland and Nero \\
\hline$"$ & 29 & 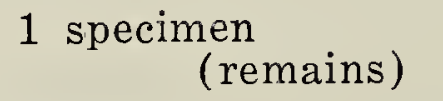 & Hadashville & Copland and Nero \\
\hline$"$ & $?$ & 8 seen & Rennie area & Fide G. Cotter \\
\hline$"$ & $?$ & 1 seen & Oakbank ( $\left.2 \frac{1}{2} \mathrm{mi} . \mathrm{NW}\right)$ & Mrs. J. Smythe \\
\hline$"$ & 29 & 1 specimen (found & Pointe du Bois (West) & R. Pohl \\
\hline$"$ & 29 & 1 specimen (shot) & $\begin{array}{l}\text { Pointe du Bois ( } 5 \mathrm{mi} \text {. } \\
\mathrm{W} \text { ) }\end{array}$ & W. Schwartz \\
\hline$"$ & $?$ & $\begin{array}{l}4 \text { specimens (found } \\
\text { shot) }\end{array}$ & Sailing Lake area & Fide G. Cotter \\
\hline January & 5 & 11 seen & Birch R. to Falcon L. & $\begin{array}{l}\text { Nero, P. Press } \\
\text { and L. Wallace }\end{array}$ \\
\hline$"$ & 5 & 1 seen & Hadashville & $\begin{array}{l}\text { M. K. McNicholl, } \\
\text { V. H. Scott }\end{array}$ \\
\hline
\end{tabular}


Table 2. Great Gray Owl records 1968-1969 (continued)

\begin{tabular}{|c|c|c|c|c|}
\hline \multicolumn{2}{|c|}{ Date } & \multirow{2}{*}{$\frac{\text { Number }}{1 \text { seen }}$} & \multirow{3}{*}{$\begin{array}{l}\text { Location } \\
\text { Braintree area } \\
\text { Winnipeg (St. James) }\end{array}$} & \multirow{2}{*}{$\frac{\text { Observer (s) }}{\text { D. I. MacDonald }}$} \\
\hline Januar & 5 & & & \\
\hline$"$ & 8 & 1 seen & & D. Sutton \\
\hline$"$ & 11 & 1 seen & Winnipeg & Miss S. Barker \\
\hline$"$ & 12 & 6 seen & Birch R. to Falcon L. & Nero and Taylor \\
\hline$"$ & 12 & 3 seen & Ste. Rita & $\begin{array}{l}\text { P. Press } \\
\text { L. Wallace }\end{array}$ \\
\hline$"$ & 13 & 8 seen & Birch River area & Nero and Taylor \\
\hline$"$ & 18 & 9 seen & Birch River to Prawda & $\begin{array}{l}\text { D. Hatch, Nero } \\
\text { and Taylor }\end{array}$ \\
\hline$"$ & 2.1 & 1 seen & Ste. Rita & Nero and Taylor \\
\hline$"$ & 22 & 1 seen & $\begin{array}{l}\text { Seven Sisters } \\
\quad(3 \mathrm{mi} . \mathrm{E})\end{array}$ & Nero and Taylor \\
\hline$"$ & 23 & 1 seen & Birch River & Nero and Taylor \\
\hline$"$ & $?$ & 1 seen & Oakbank ( $\left.2 \frac{1}{2} \mathrm{mi} . \mathrm{NW}\right)$ & Mrs. J. Smythe \\
\hline$"$ & $?$ & 2 seen & Falcon L. area & $\begin{array}{l}\text { M. K. MeNicholl } \\
\text { V. H. Scott }\end{array}$ \\
\hline Februa & $\operatorname{ary} 1-7 ?$ & 1 seen & Steinbach (5 mi. SW) & T. Wiens \\
\hline$"$ & $1-7 ?$ & 1 specimen (shot) & Tyndall & G. Hoban \\
\hline$"$ & 8 & 1 seen & Richer (2 mi. W) & C. K. Smith \\
\hline$"$ & $12-13 ?$ & 1 specimen (shot) & East Selkirk & D. C. Purvis \\
\hline$"$ & 16 & 1 specimen (found & $\begin{array}{l}\text { Prawda (banded Birch } \\
\quad \text { R. Jan. 23) }\end{array}$ & N. Dymetro \\
\hline$"$ & $17-18$ & 1 seen & Beausejour ( $7 \mathrm{mi}$. SE) & D. James \\
\hline$"$ & 19 & 1 seen (from air- & Betula L. (3 mi. W) & R. Blanchard \\
\hline$"$ & 22 & 1 seen & $\begin{array}{l}\text { Lac du Bonnet } \\
\quad(2 \mathrm{mi} . \mathrm{N})\end{array}$ & W. Banting \\
\hline$"$ & $20-27 ?$ & 1 seen & $\begin{array}{l}\text { East Selkirk (east } \\
\text { of river) }\end{array}$ & G. Beck \\
\hline$"$ & $?$ & 1 seen & Steinbach (10mi. SW) & T. Penner \\
\hline$"$ & $?$ & $\begin{array}{l}1+\text { specimen } \\
\text { (found dead) }\end{array}$ & Steinbach & P. J. Toews \\
\hline$"$ & $?$ & 3 seen & Arnaud (3 mi. SE) & J. P. King \\
\hline March & 2 & 1 specimen & Seven Sisters (Julius) & M. K. McNicholl \\
\hline$"$ & 18 & 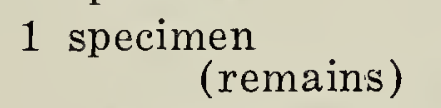 & Rennie (3 mi. E) & L. J. Bidlake \\
\hline$"$ & $23-30 ?$ & 1 specimen (road & Birds Hill (1 mi. N) & W. Johnson \\
\hline$"$ & 30 & $\begin{array}{l}1 \text { specimen (found } \\
\text { shot) }\end{array}$ & Eriksdale & I. L. Couture \\
\hline April & 5 & 1 seen & Whitemouth (6 mi. E) & M. Baker \\
\hline$"$ & 14 & 1 seen & $\begin{array}{l}\text { Riding Mountain } \\
\text { Nat'l Park }\end{array}$ & R. \& A. Cooper \\
\hline$"$ & 19 & 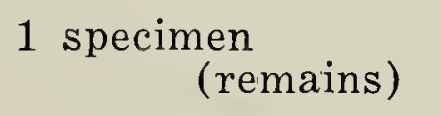 & Pinawa ( $8 \mathrm{mi} . \mathrm{E})$ & $\begin{array}{l}\text { D. R. Halliday } \\
\text { and D. Raveling }\end{array}$ \\
\hline$"$ & $19-20 ?$ & 1 specimen (found & Riverton & G. Barea \\
\hline$"$ & $23-30 ?$ & 2 seen & Rennie-Whitemouth $r d$. & R. Blanchard \\
\hline$"$ & $?$ & 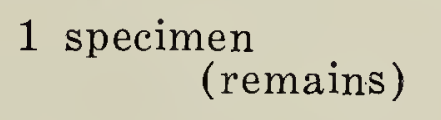 & Pinawa & C. R. Hillier \\
\hline May & $2-3$ & 1 seen & Elma (5 mi. W) & R. Blanchard \\
\hline$"$ & 12 & 1 seen & Selkirk (8 mi. N) & G. Beck \\
\hline$"$ & 15 & 1 seen & Hazel Creek & L. J. Bidlake \\
\hline$"$ & 17 & 1 seen & Hazel Creek & Nero and Taylor \\
\hline
\end{tabular}


him (Roberts, 1932: 625). No definite records are available from Manitoba for those years. On the other hand, in the winter of 1922-23, an influx occurred in Manitoba as already noted.

According to Roberts (1932:625) "it is present every winter in the northern part" of Minnesota. This does not seem to be the case for adjacent Manitoba or other parts of the province where it might be expected. There are many years when it has been unrecorded even though winter bird counts have been made regularly in various suitable areas of Manitoba. This further supports the idea that owls arriving in Minnesota and adjacent Manitoba may be from Ontario breeding grounds. Of course, there is a large area to the north and east of the entire length of Lake Winnipeg from which owls could be coming. The lake may act as a barrier during winter movements, shunting owls southward.

The possibility of a relationship between Great Gray Owl populations and small rodent cycles has received some attention. Elton (1942:224-225) noted a similarity between population cycles in Norwegian "foxes and mouselike rodents" and those of Labrador and Ungava: "these lemming and vole years (often coming simultaneously over big tracts of country) are magnets that draw in together many kinds of predators and fortify (temporarily) their numbers." Included among these predators, according to Elton, is the Great Gray Owl (as "Strix lap. ponica"). Since marked winter movements of Great Gray Owls probably follow years of "good reproduction ... in connection with decreasing frequency of small rodents in the breeding localities" (Höglund and Lansgren, 1968: 410) correlation of influx years across broad regions would seem possible. This may hold for extreme southeastern Manitoba and adjacent parts of Minnesota. There seems to be less evidence of this relationship between Manitoba and Saskatchewan. In the latter province, 13 owls, nearly half of all reported, were observed in the winter of 1955-56 (Houston, 1957), only one being recorded for that period in Manitoba.

One problem that arises in connection with assessing these records (Table 1) is the possibility that some may represent birds not far from breeding grounds. Moosehorn, Lake St. Martin, Steeprock, and Mafeking are close to remote coniferous forests and records from these localities may be unrelated to winter movements in extreme southeastern Manitoba. Increased contacts with persons working in the northern woods in winter might be of interest in this connection. T. L. Couture reported, for example, that during the winters of 1962 and 1963 he saw "quite a number of these birds while checking on timber operations in the heavy bush area North West of Riverton" (pers. corres., 1969).

\section{Distributional Changes During Influx Period}

Judging by the monthly distribution (Table 2), owls left December-January concentration points and dispersed outwards in February and March. This apparent movement may have been related to the onset of the breeding period or to increased snowfall and the difficulty of locating prey. A northward movement presumably back toward the breeding grounds, is indicated by April records. Three owls observed in late March and April at localities far beyond the main influx area, namely Eriksdale, Riding Mountain National Park, and Riverton, may have been part of this movement. The Riding Mountain record (nine and onequarter miles east of Wasagaming) is unusual in that it is the first report of a Great Gray Owl for the park (Soper, 1953; park records). The park includes a substantial area of boreal forest and the lack of even a single winter record in this locality suggests that there is little southward movement of owls from presumed breeding range in western Manitoba.

Snow cover may have influenced the distribution of owls locally. By January 5 only three inches had accumu- 
lated in the influx area. This increased to eight inches by January 15 , and to 19 inches by January 31 . To the east, at Kenora, five inches had accumulated by the end of December, and by the end of January, 32 inches of snow blanketed the Kenora region (data from Winnipeg weather office, courtesy A. H. Lamont). Observers looking for owls were aware, even in late November, that the depth of snow cover increased abruptly just east of Manitoba.

The last day on which owls were seen in large numbers was January 18 , when nine were seen within three miles late in the afternoon. Six of these were in sight at one time and it looked as if this gathering of owls presaged a movement out of the area. They appeared to be listening to each other's calls and once one turned in flight to approach another flying bird. This may have been territorial aggressiveness as reported by Godfrey (1967) or a sexual encounter. At any rate, from January 22 on, when the area was next visited, no more than one bird per day and sometimes none was found (January 26, February 2, 6 and 13) although on some days observers drove for 10 or 12 hours, covering as much as 250 miles. Although possibly only a coincidence, a concentration of owls at Duluth, Minnesota began on January 18, the same day of the above movement, to "move around more and leave the hunting territories they had established" (Green, 1969).

\section{Habitat}

The descriptions of habitat provided by Pittaway and Brunton (1969) for Great Gray Owls wintering in eastern Ontario could as well apply here: ". . . abandoned farmland with a coarse overgrowth of shrubbery and small trees is occupied. These fields are generally bordered by extensive and deep mixed or coniferous forests." In Saskatchewan, Law (1960) observed owls appearing regularly at a farm near "dense bluffs of spruce, poplar, pine and tamarack with many

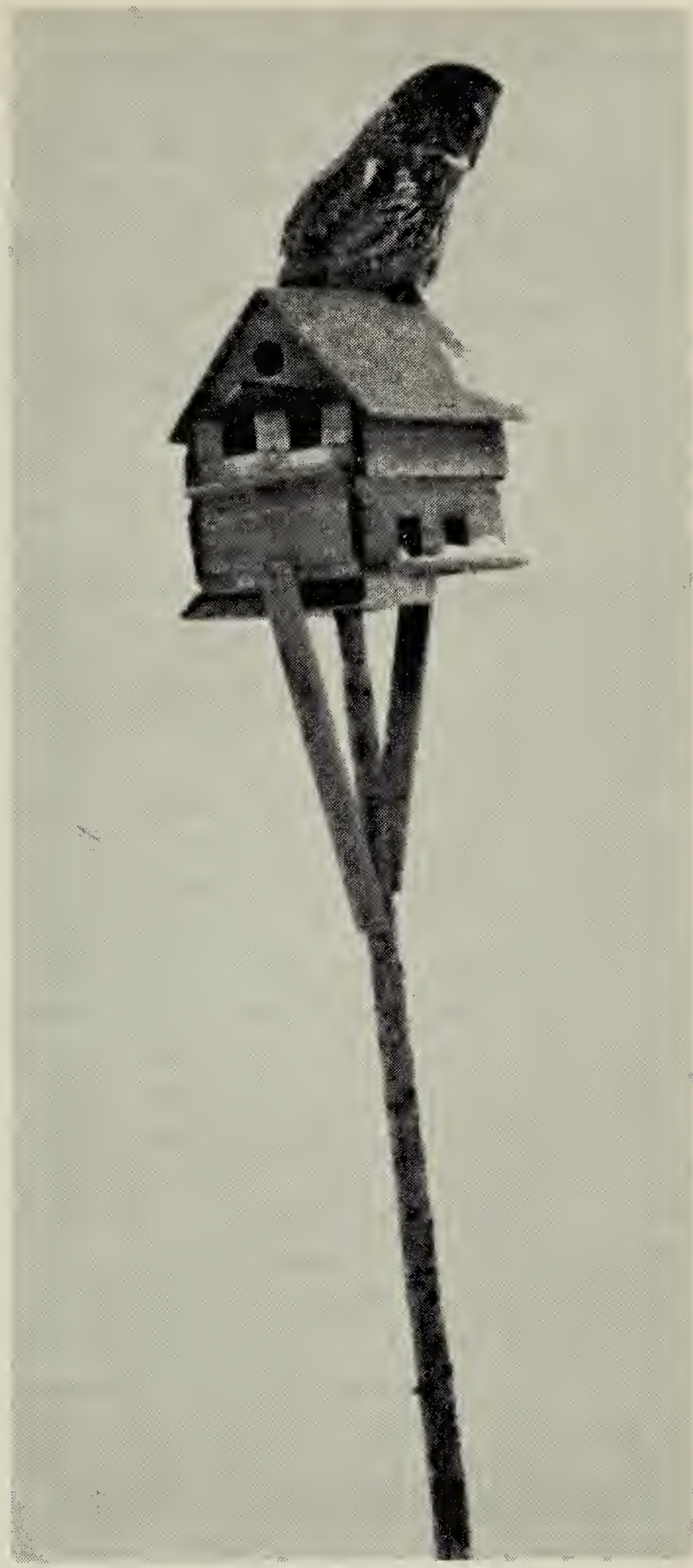

Martin house serves as perch for owl hunting mice.

open meadows, making an ideal place for the Great Gray Owl to spend the winter months..."

In our area, although birds were seen hunting in open fields, sparsely wooded tracts, jack pine, tamarack and aspen poplar stands, etc., they were seldom far from heavy spruce forests. The influx area includes two major forest reserves, both nearly surrounded by farmland. Bogs, wet meadows, old cleared land, and active farm lands provide numerous openings 
within and adjacent to the forests. Aspen poplar in various growth stages is abundant and frequently appears in mixed stands. Tree growth along streams, farm buildings and other buildings add variety to the landscape found in the area.

We observed owls perched high in large elm trees, on the tops of mature jack pine and spruce, on slim aspens that bent over with the owl's weight, on bird houses, barns, fence posts, large rocks, on the snow, in short, on almost every available kind of perch. Still, we would agree with Law (1960) that owls were most frequently found perched on a "side limb of a fair-sized poplar or spruce eight to twelve feet from the ground."

We looked for owls along roads in the late afternoon and evening when hunting behaviour was at a peak. During the day when it was cloudy or snowing, birds were also active, but on bright, warm days they usually sat close and dozed in the sun. At such times they were more easily approached than otherwise. Sometimes birds were seen at distances up to one-half mile from the road, but many were in fact observed on roadsides.

In Table 2, "Richer to Falcon Lake" denotes a 40-mile stretch of TransCanada Highway No. 1. Because more owls were found by us along this route than elsewhere and since the road was readily accessible, we travelled this route as often as we could. Great Gray Owls were seen frequently over the eastern portion of about 26 miles, from Hadashville to Falcon Lake. Thus, records from $\mathrm{H}$ ad ashville, Prawda, East Braintree (except where mileage indicates otherwise), Birch River, and Falcon Lake were relatively close together. On December 2, 12 birds were spread along the whole stretch of 40 miles; on the other hand, 11 observed on January 5 were seen in about 20 miles, and nine were seen within three miles on January 18 , six of the latter being in sight at one time. The reason for this concentration seemed to be the abundance of mice in the grassed road allowances along the righway, plus the presence of adjacent trees for perching while hunting. An even greater concentration of owls was reported in late December, 1968 at Littlefork, Minnesota (near International Falls), 16 owls having been seen in one day in a four to five mile stretch of road (Green, 1969). In forested regions at leas.t, the wide verges of modern highways may provide significant additional grassy habitat. In addition to Great Gray Owls we saw two Barred Owls, (December 2 and 5), several Great Horned Owls, and two Hawk Owls (December 1 and 5) hunting the roadsides. But if the highway thus provides cover for prey species, it also provides a hazard for predators. Great Gray Owls seemed oblivious to automotive traffic and sometimes flew slowly and carelessly across the highway even in the face of traffic. Some owls evidently died in this way, but the conspicuousness of roadside owls also makes them vulnerable to "varmint hunters" and these may take a greater toll (see Table 2).

\section{Food Habits, Hunting Behaviour, Trapping and Banding}

Food items recovered from pellets or stomach contents are shown in Table 3. Meadow Vole (Microtus pennsylvanicus) comprised 61 per cent of the total prey individuals recovered; Heather Vole (Phenacomys intermedius), seven per cent; Masked Shrew (Sorex cinereus), 30 per cent; and Norway Rat (Rattus norvegicus), two per cent. The occurrence of Heather Voles was unexpected and interesting, for there are few records of this elusive mammal in southern Manitoba. These data are in accordance with other reports on food habits of the Great Gray Owl (e.g., Godfrey, 1967; Höglund and Lansgren, 1968).

Our observations of hunting behaviour support the belief expressed by others that this owl can find its prey solely by sound (Law, 1960; Godfrey, 1967; Höglund and Lansgren, 1968), thus enabling it to locate and capture successfully prey beneath 
Table 3. Great Gray Owl pellets and stomach contents, Manitoba, 1968-69

1. May, 1968. Near The Pas. Pellet from near nest-site.

Nicrotus pennsylvanicus - 7

2. November 9, 1968. Removed from stomach of female found dead southeast of Carrick.

Microtus pennsylvanicus - 3

Phenacomys intermedius - 1

3. December 5, 1968. Pellet observed ejected by owl perched on large boulder beside Highway No. 1, 5 miles east of Prawda.

Microtus pennsylvanicus - 3

Phenacomys intermedius - 1

Sorex cinereus - 1

4. December 28, 1968. Removed from stomach of road kills. 2 miles south, 3 miles west of Hadashville.

Micr.tus pennsylvanicus - 5

Sorex cinereus - 2

5. December 29, 1968. Removed from stomach of male shot by hunter 5-7 miles west of Pointe du Bois.

Microtus pennsylvanicus - 3

Phenacomys intermedius - 1

6. December 29, 1968. Removed from stomach of male found dead on road west of Pointe du Bois.

Rattus norvegicus - 1

7. ca. 1sit week February, 1969. Removed from stomach of specimen shot by farmer near Tyndall.

Microtus pennsylvanicus - 2

Sorex cinereus - 1

8. April 19 or 20,1969 . Removed from stomach of male found dead at Riverton.

Microtus pennsylvanicus - 4

9. Late winter 1968-69. Removed from stomach of male submitted to taxidermist from southeastern Manitoba.

Sorex cinereus - 10

Microtus pennsylvanicus - 1

snow cover. When listening to a mouse it may on occasion seem completely unaware of an approaching observer so much does it seem to concentrate on its prey. Pittaway and Brunton (1969) wrote that "it seems almost hypnotized by the prey activity below."
Late one afternoon (January 18) we found a bird perched about 12 feet up in a small tree steadfastly peering down toward the ground where something held its attention. We set a trap with mice on the snow within 50 feet, but the owl seemed uninterested and kept peering down at one spot in the snow. Later, when it was almost dark, an attempt was made to snare the owl. Robert Taylor was unable to see the wire loop on the end of his snare-pole and after making several vain attempts to bring the loop over the owl's head accidentally bumped the owl's beak with the end of the pole. Only then did the owl fly away! We were all convinced that the owl had been concentrating all this while on a mouse beneath the snow.

Squeaking sounds attracted them and we tried thus to draw their attention to our baited traps. On January 18, as we stood by our car on the edge of the highway squeaking for a bird in an adjacent field, a second bird, evidently attracted by our squeaking, flew towards us and then pounced upon a small lump of brownish ice in the middle of the highway about 75 feet away. It sat for a few seconds looking down at its "prey" before it flew away.

Good visual acuity in Great Gray Owls has been reported by Pittaway and Brunton (1969) who observed that owls responded immediately to a mouse appearing on top of the snow at 200 yards distance. Response at similar distances to traps baited with live animals was observed by us on several occasions. Bal-chatri traps of several kinds, that is, hardware cloth cages covered with slip-nooses of monofilament nylon (see Berger and Mueller, 1959) were used to trap owls for banding and photography.

We set out traps using live House $\mathrm{Sparrows}$ (Passer domesticus), Meadow Voles, Gapper's Red-backed Mice (Clethrionomys gapperi), black, gray, and white House Mice (Mus musculus), and a Red Squirrel (Tamiasciurus hudsonicus). Traps were always set as close as possible 


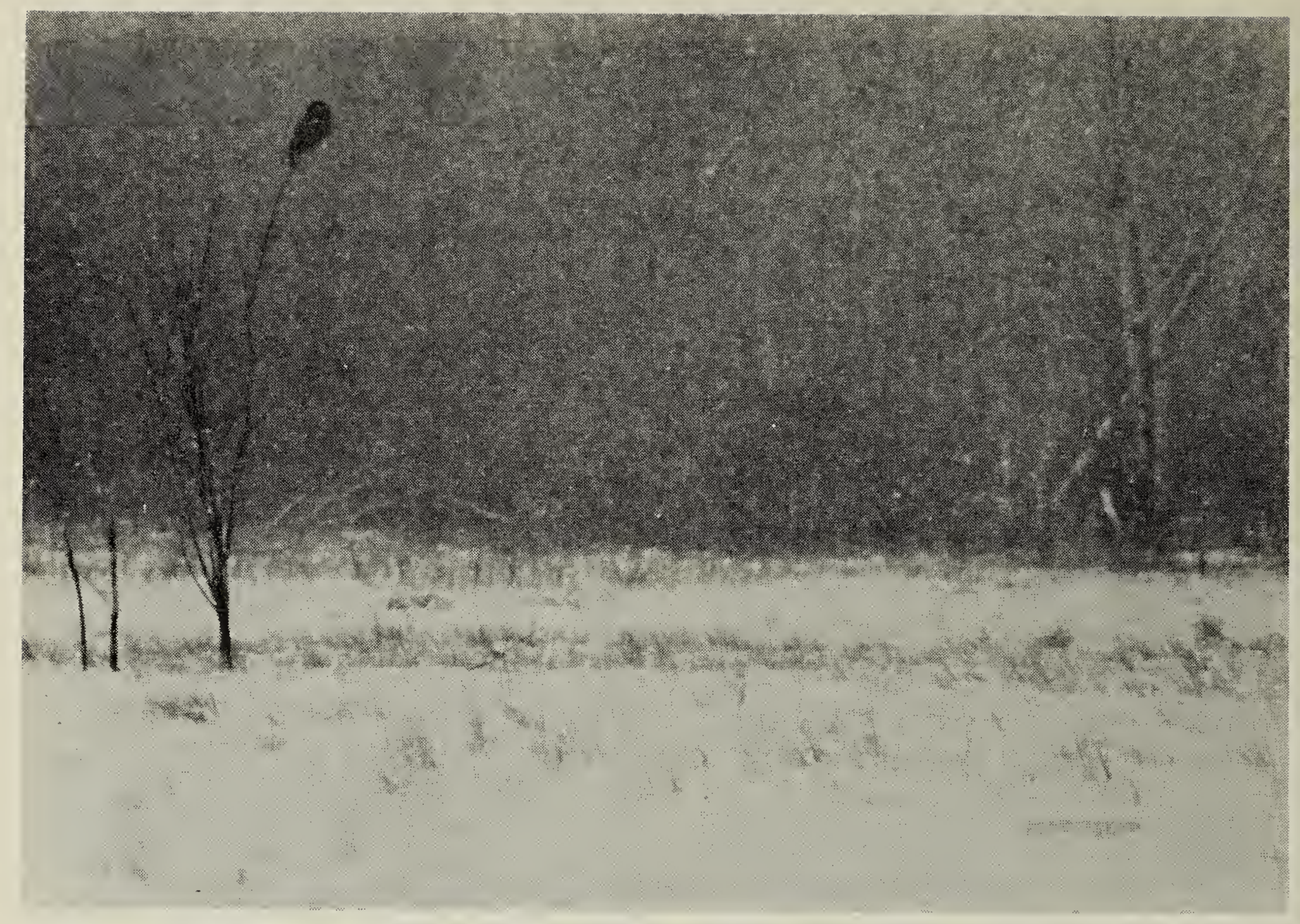

Response to baited trap (lower right). Owl watches closely.

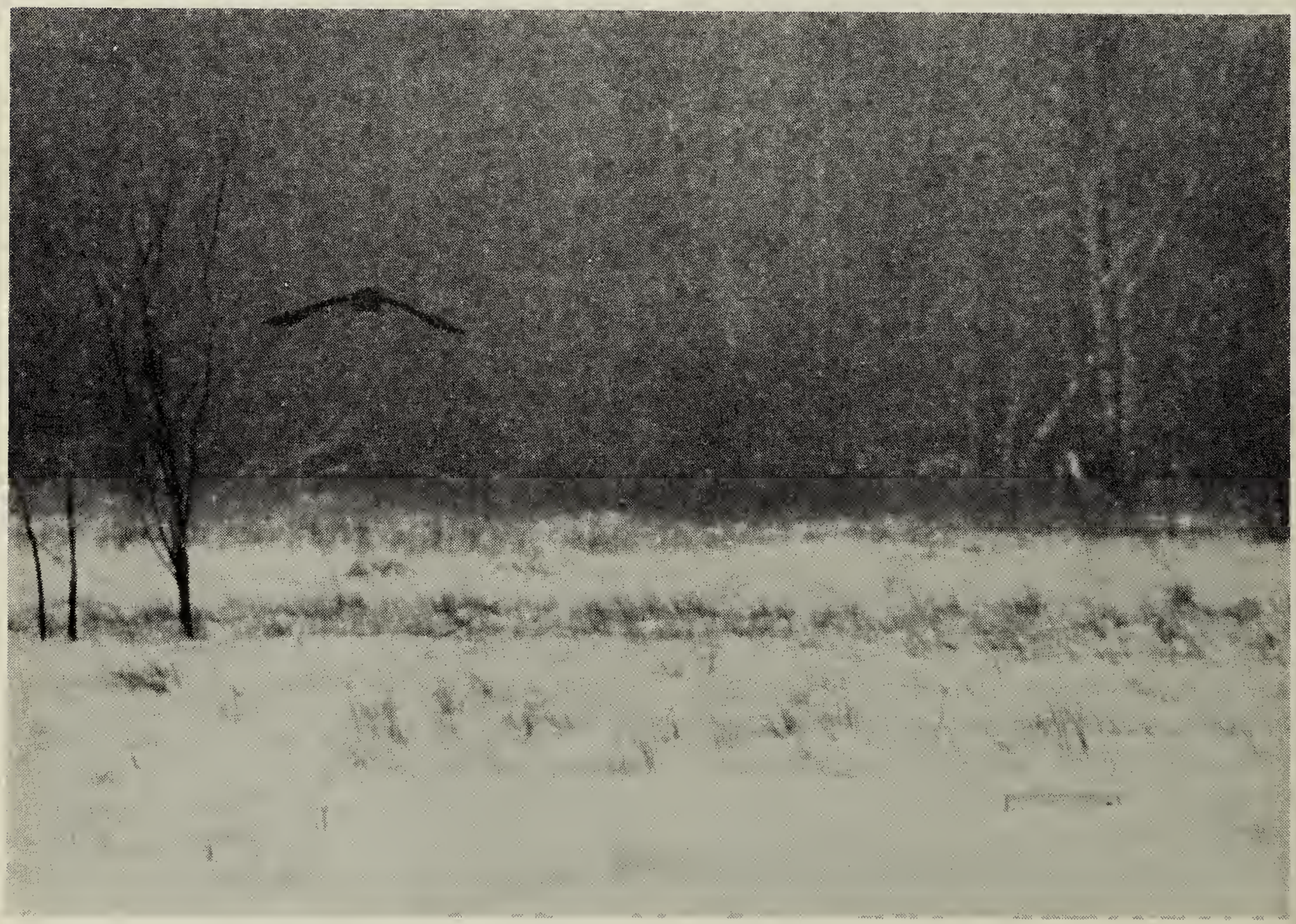

Owl launches directly towards trap. 
color-marked birds) would help determine the origin of the owls wintering in Manitoba and Minnesota.

\section{Relationship with Other Species}

The report by Lawrence (1926a) of a taxidermist finding the remains of a Great Gray Owl in the stomach of a Golden Eagle is of some interest. Although details are missing from the report, the eagle, which was shot, was presumably taken in Manitoba and in the winter of 1925-26, for Lawrence's column was written in May. In an extensive study of the Great Gray Owl in Sweden, Höglund and Lansgren (1968) record only one possible case of a Golden Eagle preying upon this species.

Our observations of contacts between Great Gray Owls and other species of birds are limited but similar to reports by others (e.g., Law, 1960; Pittaway and Brunton, 1969), there being nothing to indicate that birds regard this species as an enemy. On a few occasions a Common Raven made a casual pass at a perched owl and once a Gray Jay flew in briefly. The owls were otherwise ignored though there were lots of opportunities for Black-capped and Boreal chickadees, Gray and Blue jays, and other species, to come in contact with them.

\section{Non-breeding or Nesting?}

The possibility that Great Gray Owls may nest within the influx area following a winter of abundance needs to be considered. The owls present in the area through April and well into May (Table 2) could have been nesting but we have no data to support this. Winter influxes probably include a large number of sub-adult birds, and these latter may, as non-breeders, account for late season stragglers.

Observations of a bird on the Hazel Creek, about 13 miles west of Elma, on May 15 and May 17, were inconclusive. The creek, which runs through large black spruce bogs, is bordered by a riparian forest of black poplar, elm and ash, often of mature size, which seemed ideal nesting habitat.
Taylor and I found a bird moving along the edge of the creek at 8:30 a.m., May 17, probably the same one seen two days before and two miles farther upstream by L. J. Bidlake. We followed it along in a canoe for half an hour, hoping to follow it to a nest site, but its hunting was desultory and unsuccessful. After moving upstream several times it settled on a short limb tight against the trunk of a large black poplar as if prepared to go to sleep. Two and one-half hours later when we returned it was still in the same position, so protectively colored as to be almosit invisible. Although we knew the exact spot where it had gone to roost, we had to paddle close before we were able to pick it out from the striped pattern on the tree.

Further checks of this area on May 22 and June 28 failed to turn up the owl. It needs to be appreciated, however, that niore than 150 square miles of nearly inaccessible bog and forest surround the creek at this point.

\section{Conservation}

The tameness and conspicuousness of this large owl are characters that have been mentioned by nearly every observer. It is this aspect that makes it unlikely that the species could long persist in proximity to man, and this may be a major factor limiting its distribution. Baines (1954) remarked that "it is quickly exterminated as settlement takes place."

In spite of the large numbers of Great Gray Owls seen in Manitoba in the winter of 1968-69 it should be remembered that this bird is rare. Jones (1954) considered it "one of the rarest birds now found in Canada", noting that for two years in Alberta "Al Oeming . . . and myself have searched in vain for the nest... Our travels of over ten thousand miles have taken us through hundreds of miles of virgin timber on horse-back and often by foot. To date not one of these birds has been seen alive!"

If fall and winter movements are "to be understood as a more or less pronounced starvation migration" 
(Höglund and Lansgren, 1968:410), the decimation of Great Gray Owls in winter may be a regulating factor of value to the species. However, their vulnerability is such that excessive numbers are lost in each influx. In Minnesota, Janet Green observed (1969) that "many of the owls died before they were able to make the return journey", the death of 11 owls resulting from shooting, starvation, auto collision and predation. In Manitoba, two dozen were found dead, shooting (13 birds), and auto collision (8?) accounting for the largest number. Starvation was also noted, one observer having found an emaciated bird where it "had fallen off a branch ... " A number of birds that we handled were noticeably thin.

Natural mortality is something the Great Gray Owl has lived with for a long time, but shooting is something that should be eliminated. A great deal more must be done to let the public know that these owls are rare, valuable and legally protected. In December, 1968, in Manitoba, one person was prosecuted and fined $\$ 50.00$ and costs under The Wildlife Act for shooting a Great Gray Owl. In this case, a Conservation Officer found a hunter in the field with the freshly shot bird. Some birds, suspected of having been shot, were also seized during the influx period, the holders, for lack of clear evidence of guilt, not being charged.

Taxidermists mounted a number of Great Gray Owls for people who reported finding them dead during the influx period. Persons wishing to have a protected bird mounted are required to apply in writing (and taxidermists are required to so advise them) to the Wildlife Branch of the Manitoba Department of Mines and Natural Resources for a permit. In some cases, permission to have a bird mounted seems to have been granted by field staff. Where possible, such birds are supposed to be examined, to see if they have been shot, but this is not always done. Permits have been issued without anyone other than the taxi-

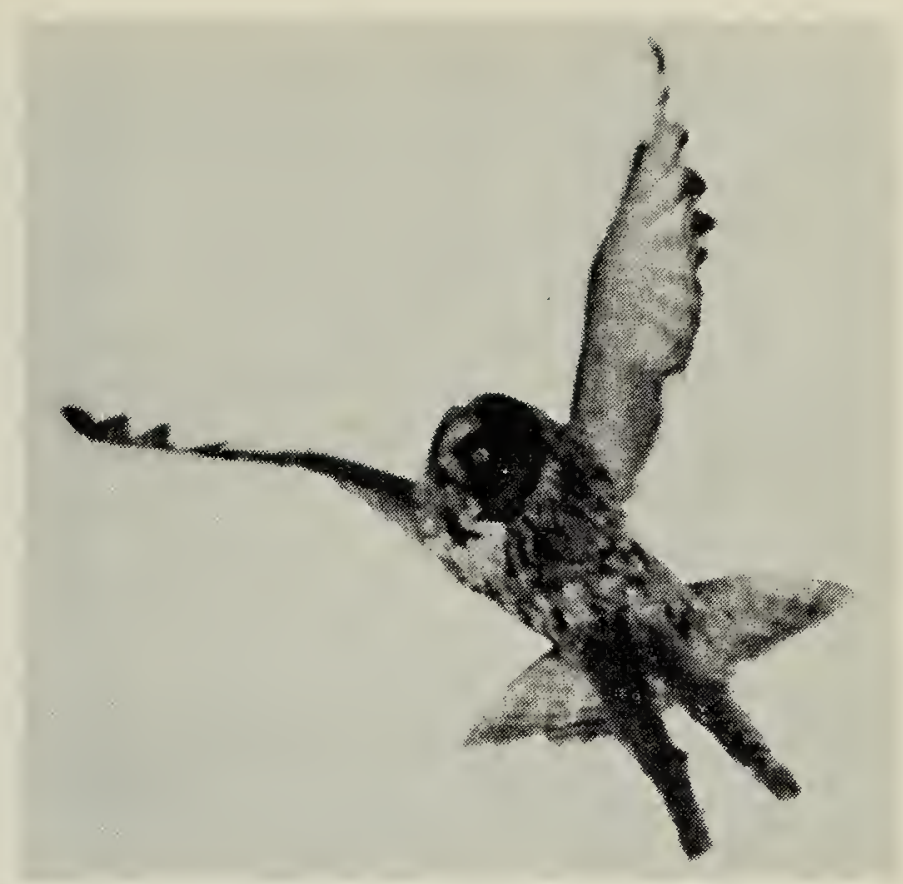

Release of banded owl.

Note the long legs and small feet.

dermist having seen or identified the bird. Departmental records of permits issued for this purpose in some cases failed to give an exact identification, e.g., "owl" appeared on one, "black owl" on another.

Local taxidermists often went to some effort to provide us with carcasses and data on Great Gray Owls being handled by them (though some records were unfortunately vague or even mixed), but they are not required to do so. The whole aspect of having protected birds mounted should come under tighter regulations. There is little doubt that the Golden Eagle or Great Gray Owl in the taxidermist's shop window encourages hunters to seek these trophies. Birds that die from starvation or collision or those found shot or confiscated could be mounted and used for educational purposes in schools or by conservation groups. But there is no reason why rare or protected birds should any longer be preserved as trophies or curiosities in private homes.

\section{Acknowledgments}

Thanks are due the numerous persons listed in Table 1, who contributed records from previous years, and those listed in Table 2 who observed Great Gray Owls in 1968-69 and whose records provide much of 


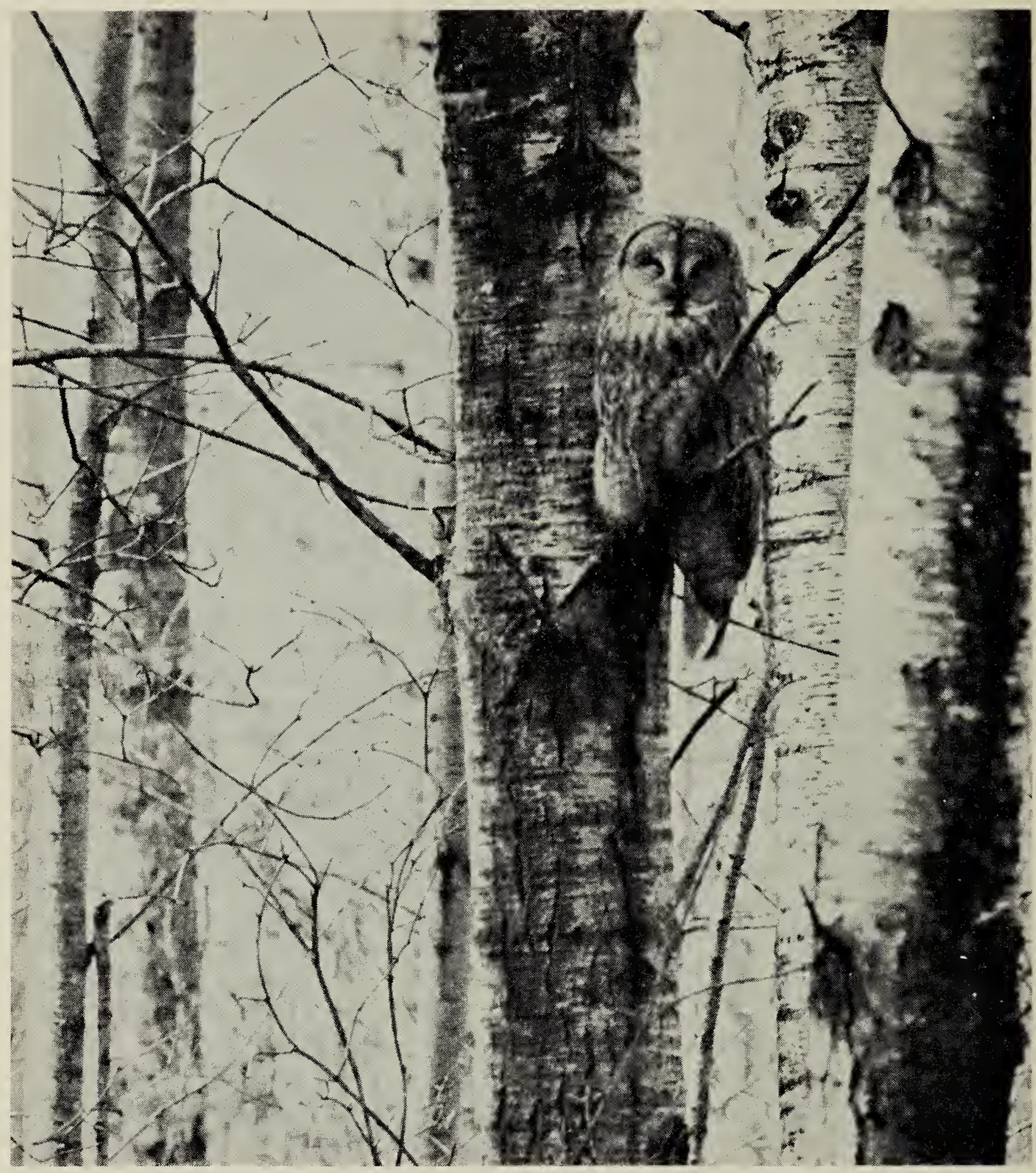

Photos by R. R. Taylor

Great Gray Owl concealment posture. Facial and body plumage patterns blend with balsam poplar trunk.

the basis for this report. The latter list includes staff from the Canadian Wildlife Service, the Wildlife Branch and Regional Offices, Manitoba Department of Mines and Natural Resources, and the Parks Branch, Manitoba Department of Tourism and Recreation. In addition to those listed, I am grateful to M. Bilan, G. S. Parsons, E. Sainsbury, R. Squires, and M. S. Thorvaldson, Wildlife Branch and Regional Offices. Assistance in various ways was provided by J. C. Barlow, Mrs. E. Chapman, K. Gardner, W. E. Godfrey, V. Guarino, K. Hawkins, H. Hosford, Dr. S. L. Iverson, Miss H. Johnson, A. Kelner, A. D. Kelner, E. Kempf, T. A. Laine, H. Mossop, Dr. M. Ray, A. Ruest, R. W. Sutton, R. Telesky, B. N. Turner, R. J. Walker, S. Waller, and D. W. A. Whitfield. 
Particular thanks are extended to W. H. Beck, who identified the contents of owl pellets and stomachs. M. Miller assisted in the preparation of the latter material. H. W. R. Copland and R. R. Taylor deserve credit for their boundless enthusiasm and energy in pursuit of owls. Herb Copland also drew the figures and assisted in searching for published records. Bob Taylor directed the banding and photographic operations. His photographs say more than any of us can about the beauty and enchanting character of the Great Gray Owl.

\section{LITERATURE CITED}

Allin, A. E. 1966. The Canadian Lakehead. Loon, $38: 65-69$.

Baird, S. F., J. Cassin, and G. N. Lawrence. 1860. The birds of North America; the descriptions of species based chiefly on the collections in the museum of the Smithsonian Institution. J. P. Lippincott \& Co., Philadelphia. $1005 \mathrm{pp}$.

Baines, K. E. 1954. It is a foolish bird. Blue Jay, $12(2): 20$.

Berger, D. D., and H. C. Mueller. 1959. The bal-chatri:a trap for the birds of prey. BirdBanding, $30: 18-26$.

Elton, C. 1942. Voles, mice and lemmings. Oxford Univ. Press, $496 \mathrm{pp}$.

Godfrey, W. E. 1966. The birds of Canada. Nat'l Mus. Can. Bull. No. 203, Biol. Series No. 73 . Ottawa. 428 pp. 69 color plates, 71 line drawings, 2 maps.

Godfrey, W. E. 1967. Some winter aspects of the Great Gray Owl. Can. Field-Nat., 81: 99-101.

Green, Janet C. 1966. Influx of northern owls, winter 1965-66. Loon, 38: 44-45.

Green, Janet C. 1969. Northern owl invasion winter, 1968-1969. Loon, 41:36-39.

Hoglund, N. H., and E. Lansgren. 1968. The Great Gray Owl and its prey in Sweden. Viltrevy, 5: 363-421.

Houston, S. 1957. The Great Gray Owl in Saskatchewan. Blue Jay, 15:150-153.

Jehl, J. J., Jr., and Mrs. Blanche Smith. MS. Birds of the Churchill-Cape Churchill region, Manitoba.

Jones, E. T. 1954. The Great Gray Owl. Blue Jay, $12(1): 8$.

Law, C. 1960. The Great Gray Owl of the woodlands. Blue Jay, 18: 14-16.

Lawrence, A. G. 1926a. Kismet. "Chickadee Notes" No. 267. Winnipeg Free Press. May $6,1926$.

Lawrence, A. G. 1926b. Breeding records. "Chickadee Notes" No. 271. Winnipeg Free Press. June 3, 1926.

Lawrence. A. G. 1928. The Great Grey [sic] Owl. "Chickadee Notes" No. 364. Winnipeg Free Press. March 15, 1928.
Lawrence, A. G. 1933. Winter birds at Whitemouth. "Chickadee Notes" No. 620. Winnipeg Free Press. February 10, 1933.

Lawrence, A. G. 1934. Winter birds at Whitemouth. "Chickadee Notes" No. 674. Winnipeg Free Press. February 23, 1934.

Lawrence, A. G. 1949. Three more for Churchill list. "Chickadee Notes" No. 1468. Winnipeg Free Press. July 8, 1949.

Lawrence, A. G. 1950. Northern owls are daylight hunters. "Chickadee Notes" No. 1543. Winnipeg Free Press. December 15, 1950.

Mitchell, B. 1969. The Great Gray Owl. Wildlife Crusader, 15:24-25.

Mossop, H. 1956. More winter birds. "Chickadee Notes" No. 52. Winnipeg Free Press. January 13, 1956.

Mossop, H. 1959. Great Gray Owls in Winnipeg. "Chickadee Notes" No. 255. Winnipeg Free Press. December 4, 1959.

Mossop, H. 1960. Owl casualties. "Chickadee Notes" No. 260. Winnipeg Free Press, January 8, 1960.

Mossop, H. 1965. Largest owl growing scarce. "Chickadee Notes" No. 535. Winnipeg Free Press. April 17, 1965.

Mossop, H. 1966a. Winter bird census results. "Chickadee Notes" No. 574. Winnipeg Free Press. January 15, 1966.

Mossop, H. 1966b. A rare invasion of northerners. "Chickadee Notes" No. 585. Winnipeg Free Press. April 2, 1966.

Norman, E. S. 1920. Additions to the birds of Shoal Lake, Manitoba. Can. Field-Nat., $34: 154$.

Parmalee, D. F. 1968. Nesting of the Great Gray Owl in Manitoba. Blue Jay, 26:120121.

Pittaway, R., and D. F. Brunton. 1969. The Great Gray Owl - fact and fiction. Trail \& Landscape, $3:$ 94-97.

Roberts, T. S. 1932. The birds of Minnesota. Univ. of Minnesota, Vol. 1. 691 pp., 49 plates.

Robinson, E. 1954. Found nest of the Great Grey [sic] Owl. Blue Jay, 12(2): 20.

Shortt, A. H. 1951. "Wild Wings". Winnipeg Tribune. February 3, 1951.

Shortt, A. [H. 1 1959. Rare northern owl visits city. "Wild Wings". Winnipeg Tribune. November 28, 1959.

Shortt. T. M., and S. Waller. 1937. The birds of the Lake St. Martin region, Manitoba. Contrib. Roy. Ont. Mus. Zool. No. 10, 51 pp.

Soper, J. D. 1953. The birds of Riding Mountain National Park, Manitoba, Canada. Wildlife Mgt. Bull. Series 2, No. 6. Can. Dept. Res. \& Devel., Nat'l. Parks Br., Can. Wildlife Serv., Ottawa. 54 pp. +8 photos, 1 map. Mimeo.

Taverner, P. A., and G. M. Sutton. 1934. The birds of Churchill, Manitoba. Annals Carnegie Mus., Vol. 23, pn. 1-83, plus 14 plates.

Thompson. E. E. ( = E. T. Seton). 1891. The birds of Manitoba. Proc. U.S. Nat'l Mus., Vol. 13, 1890, pp. 457-643, Washington.

Vogt, W. 1935. Flying for ducks. Bird-Lore, $37: 312-316$.

Weir, T. R. 1960. Economic atlas of Manitoba. Man. Dept. Industry and Commerce. $81 \mathrm{pp}$. 